\title{
THE EFFECT OF ADSORBENT TYPE AND RATIO ON REMOVAL OF METHYLENE BLUE AND ITS ISOTHERM ADSORPTION
}

\author{
Lia Cundari ${ }^{1}$, Eki Saputra ${ }^{1}$, Agus Suranto ${ }^{1}$, Y. Yandriani ${ }^{1}$ and R. Rosalina ${ }^{2}$ \\ ${ }^{I}$ Chemical Engineering Department, Faculty of Engineering, Sriwijaya University \\ Jl. Raya Palembang-Prabumulih KM. 32 Indralaya Ogan Ilir (OI), South Sumatra 30662 \\ ${ }^{2}$ Politeknik ATI Padang \\ Jl. Bungo Pasang Tabing Padang, West Sumatra, 25171 \\ E-mail: liacundari@ft.unsri.ac.id
}

Received: 14 January 2020

Revised: 21 April 2020

Accepted: 28 April 2020

\begin{abstract}
THE EFFECT OF ADSORBENT TYPE AND RATIO ON REMOVAL AND ISOTHERM ADSORPTION OF METHYLENE BLUE. Methylene Blue (MB) is one of the dye that are widely used in the textile industry. The wastewater from textile industry that contain $\mathrm{MB}$ can reduce the oxygen level in water bodies. This study aims to determine the efficiency of the adsorbent in MB removal and to analyze the isotherm adsorption. The variations conducted in this research was the type of adsorbent and its ratio. The activated carbon that used as adsorbent was fresh betel nut (Cyrtostachys lakka) activated carbon (A), regenerated betel nut activated carbon (B), and coconut shell activated carbon (Cocos nucifera) (C). The type of adsorbent was $\mathrm{AB}, \mathrm{AC}$, and $\mathrm{BC}$ with ratio of $1: 1,1: 2,1: 3,2: 1$, and $3: 1$. The $\mathrm{MB}$ concentration was analyzed by using UV-Vis spectrophotometer. Isotherm adsorption was calculated based on Freundlich and Langmuir. The best results showed that the combination of fresh and regenerated betel nuts (AB) with ratio of 3:1 can remove $97.77 \%$ of $\mathrm{MB}$. The adsorption process of MB in aqueous solution followed the Langmuir model with regression over 0.99 and adsorption capacity in the range of $2.14 \mathrm{mg} / \mathrm{g}-3.53 \mathrm{mg} / \mathrm{g}$.
\end{abstract}

Keywords: Adsorption, Adsorbent type, Isotherm, Methylene blue, Ratio

\begin{abstract}
ABSTRAK
EFEK JENIS DAN RASIO ADSORBEN PADA PENGHILANGAN METILEN BIRU DAN ISOTERM ADSORPSINYA. Methylene Blue (MB) adalah salah satu pewarna yang banyak digunakan dalam industri tekstil. Air limbah dari industri tekstil yang mengandung MB dapat mengurangi kandungan oksigen dalam air. Penelitian ini bertujuan untuk menentukan efisiensi adsorben dalam menghilangkan MB dan untuk menganalisa isoterm adsorpsinya. Variasi yang dilakukan dalam penelitian ini adalah jenis adsorben dan rasionya. Karbon aktif yang digunakan sebagai adsorben adalah karbon aktif biji pinang hias (Cyrtostachys lakka) (A), karbon aktif biji pinang hias yang diregenerasi (B), dan karbon aktif tempurung kelapa (Cocos nucifera) (C). Jenis adsorben adalah $\mathrm{AB}, \mathrm{AC}$, dan $\mathrm{BC}$ dengan rasio 1:1, 1:2, 1:3, 2:1, dan 3:1. Konsentrasi MB dianalisis dengan menggunakan spektrofotometer UV-Vis. Adsorpsi isoterm dihitung berdasarkan isoterm Freundlich dan Langmuir. Hasil terbaik menunjukkan bahwa kombinasi karbon aktif dari biji pinang hias dan regenerasinya (AB) dengan rasio 3:1 dapat menghilangkan 97,77\% MB. Proses adsorpsi MB dalam larutan mengikuti model Langmuir dengan regresi lebih besar dari 0,99 dan kapasitas adsorpsi sebesar 2,14 mg/g - 3,53 mg/g.
\end{abstract}

Kata kunci: Adsorpsi, Jenis adsorben, Isoterm, Metylene blue, Rasio

\section{INTRODUCTION}

Synthetic dyes are pollutant aspects that disrupt the ecosystem and reduce the water quality. The textile industry is one of industry that uses large amounts of synthetic dyes. In the textile industry there are three 
types of dyes, namely anionic, cationic and non-ionic dyes. The widely use of the type of cationic dyes in the textile industry is Methylene Blue [1]. The negative effect of this textile industry was the wastewater that contain organic materials that difficult to naturally degrade. Various methods have been carried out such as the process of coagulation/flocculation [2], cation exchange membrane [3], electrocoagulation [4], fenton reagent [5], and adsorption [1], [6]. The adsorption method using various types of adsorbents is still the most profitable method because of its high effectiveness and adsorption capacity, and low operational costs [7], [8]. The adsorption method has economic savings potential, because the activated carbon that has been used can be derived from agriculture waste and regenerated again through a desorption mechanism.

The activated carbon that used as adsorbent to methylene blue (MB) degradation was fresh betel nut activated carbon (A), regenerated betel nut activated carbon (B), and coconut shell activated carbon (C). Activated carbon that produce from betel nut (Cyrtostachys lakka) was a potential adsorbent to remove methylene blue [9], COD, BOD, TSS, and color [10]. The regenerated betel nut activated carbon removed $98.98 \%$ of methylene blue (MB) with an adsorption capacity of $3.57 \mathrm{mg} / \mathrm{g}$ and adsorption isotherm followed the Langmuir model [9]. The coconut shell activated carbon was bought from the market base.

The removal of methylene blue onto KATK (Coconut Shell Activated Carbon) and KABB (Coal Activated Carbon) were respectively $48.54 \%$ and $66.79 \%$ [11]. The regenerated activated carbon that produce from spent adsorbent in industrial application degraded $98 \%$ of methylene blue [12]. The regenerated sawdust reduced $90 \%$ of MB [13]. A study on adsorption capacity and isotherm in batches using regenerated of commercial activated carbon obtained $61.73 \mathrm{mg} / \mathrm{g}$ and $96.30 \%$ removal for physical, and $53.72 \mathrm{mg} / \mathrm{g}$ and $83.80 \%$ for chemical method [14]. The activated carbon based on winemaking waste that utilized to remove the MB fitted to Langmuir isotherm with adsorption capacity of 714 $926 \mathrm{mg} / \mathrm{g}[15]$.

The comparison of ability between the fresh and regenerated betel nut activated carbon, also compare to the commercial activated carbon based on coconut shell were conducted to get the best adsorbent type and ratio to adsorp of MB. Based on previous research, a study of the effect of type and ratio of an adsorbent to the MB removal was conducted to determine the adsorption efficiency and isotherm. The concentration data from the experimental was used to calculate the isotherm as Freundlich and Langmuir.

\section{EXPERIMENTAL METHOD}

In this study the independent variables used were the type of adsorbent and adsorbent ratio. The type of adsorbent was activated carbon made from fresh betel nut (Cyrtostachys lakka) (A), regenerated betel nut (B), and coconut shell (Cocos nucifera) (C), while the ratio was 1:1,1:2, 1:3, 2:1, and 3:1. The dependent variable was the concentration of MB that adsorbed.

The A adsorbent was carried out by using pyrolysis method at $500^{\circ} \mathrm{C}$ for 1 hour and then activated by using $0.5 \mathrm{M} \mathrm{HCl}$ for 1 hour immersion time. The $\mathrm{B}$ adsorbent was obtained from chemical-physical regeneration methods [9]. The spent of betel nut activated carbon was washed and dried, and then activated chemically with $\mathrm{HCl}$ solution $7 \mathrm{~N}$ for 30 minutes immersion. Activated carbon that chemically active was dried in oven at the $105^{\circ} \mathrm{C}$. Dry adsorbent was activated by physical method at $190^{\circ} \mathrm{C}$ for 1 hour. The $\mathrm{C}$ adsorbent was a commercial grade. The size particle of all the adsorbent types was 60 mesh.

The standard curve of methylene blue solution was done by making a standard solution with concentrations of 20, 40, 60, 80 and $100 \mathrm{mg} / \mathrm{l}$. Each standard solution was measured for absorbance using a UV-Vis spectrophotometer at a wavelength of $560.5 \mathrm{~nm}$. The next step was make a standard of methylene blue curve by plotting concentration versus absorbance. The experiment was carried out by preparing $200 \mathrm{ml}$ of methylene blue solution. Amount of 6 grams adsorbents were mixed into MB solution with stirring speed of 150 $\mathrm{rpm}$. The adsorbents were contained of two types of adsorbent, which were $\mathrm{AB}, \mathrm{AC}$, and $\mathrm{BC}$ with the ratio of 1:1, 1:2, 1:3,2:1, and 3:1. Contact time between adsorbent and MB solution was $0-25$ minutes with 5-minute intervals for each experiment. The filtrates were analyzed by using a UV-vis spectrophotometer.

The value of adsorption efficiency or \%-removal was determined using the equation in (1). Adsorption efficiency is a comparison between the difference of the initial $\left(\mathrm{C}_{\mathrm{o}}\right)$ and final $\left(\mathrm{C}_{\mathrm{e}}\right)$ concentration $(\mathrm{mg} / \mathrm{l})$ with the initial concentration $\left(\mathrm{C}_{\mathrm{o}}\right)(\mathrm{mg} / \mathrm{l})$.

$$
\% \text { - Removal }=\frac{C_{\mathrm{o}}-C_{\mathrm{e}}}{C_{\mathrm{o}}} \times 100 \%
$$

The approach to the adsorption isotherm can be explained by the Freundlich equation. If the concentration of solution in equilibrium is plotted as an ordinate and the concentration of the adsorbate in the adsorbent as abscissa in logarithmic coordinates, a gradient of $n$ and intercept will be obtained $[9,10,15,16]$. The Freundlich isotherm model explains that the adsorption process on the surface is heterogeneous where not all adsorbent surfaces have adsorption power. The Freundlich isotherm model shows that the adsorbate layer formed multilayer on the surface of the adsorbent. The adsorption capacity of Freundlich isotherm can be calculated from the equation (2). $q_{e}$ is the amount of adsorbate adsorbed $(\mathrm{mg} / \mathrm{g}), \mathrm{K}_{\mathrm{F}}$ is the Freundlich constant $(1 / \mathrm{mg})$, and $\mathrm{n}$ is adsorption constant. The constants of this model are calculated by 
the slope and intercept of the plot obtained from $\log \mathrm{q}_{\mathrm{e}}$ versus $\log \mathrm{C}_{\mathrm{e}}$

$$
\log \mathrm{q}_{\mathrm{e}}=\log k_{f}+\frac{1}{n} \log C_{e}
$$

The langmuir equation assumes that the surface of the adsorbent is homogeneous, and a site can only be occupied by one pollutant molecule [9], [10], [15], [16]. The Langmuir equation is written at equation (3). The $\mathrm{q}_{\mathrm{m}}$ and $\mathrm{K}_{1}$ are the maximum adsorption capacity (mg/ g) and langmuir constant $(1 / \mathrm{mg})$. The constants associated with the Langmuir isotherm model are calculated by the slope and intercept of the plot, which is obtained from $C_{e} / q_{e}$ versus $C_{e}$. The $q_{e}$ can be calculated with equation (4), where $\mathrm{V}$ is the volume of the solution that treated (l) and $\mathrm{m}$ is the weight of the adsorbent used $(\mathrm{g})$.

$$
\begin{aligned}
& \frac{C_{e}}{q_{e}}=\frac{1}{q_{m} \mathrm{~K}_{l}}+\frac{C_{e}}{q_{m}} \\
& \mathrm{q}_{\mathrm{e}}=\left(C_{\mathrm{o}}-C_{\mathrm{e}}\right) \times \frac{\mathrm{V}}{\mathrm{m}}
\end{aligned}
$$

\section{RESULT AND DISCUSSION}

Based on the testing of moisture content in the activated carbon, amount of $0.051 \%, 0.061 \%$, and $1.7291 \%$ were obtained for $\mathrm{A}, \mathrm{B}$, and $\mathrm{C}$ adsorbent respectively. The results of the water content obtained from this study have met the quality standards of activated carbon according to SNI 06-3730-1995. Water content found in the activated carbon of betel nut that come from regeneration was greater than the fresh one. This happened due to the raw material has undergone adsorption to saturation, so that the pores have been filled with adsorbate and water. After undergoing chemical-physics activation, filled pores still was found. This is in line with the research of Sahara et al. (2017) which states that high water content is caused by the presence of water bound to either vapor or liquid which is trapped in charcoal molecules that do not come out during low temperature activation [17].

The result of adsorption efficiency for $\mathrm{AB}$ activated carbon to reduce the methylene blue content was summarized in Figure 1. The removal was ranged from 88.46 to $97.77 \%$. The maximum removal obtained at $\mathrm{AB}$ ratio of $3: 1$ at 20 minutes contact time. At $\mathrm{AB}$ ratio of $3: 1$, the efficiency decreased from $97.77 \%$ to $97.34 \%$ at 20 and 25 minutes, it happened because the activated carbon has reached equilibrium. The influence of contact time occurs when adsorption has not reached equilibrium, after equilibrium is reached the adsorption will decrease [18]. When the adsorption has reached the equilibrium point, the adsorbate that bonded to the adsorbent can desorbed by releasing the dyestuff.

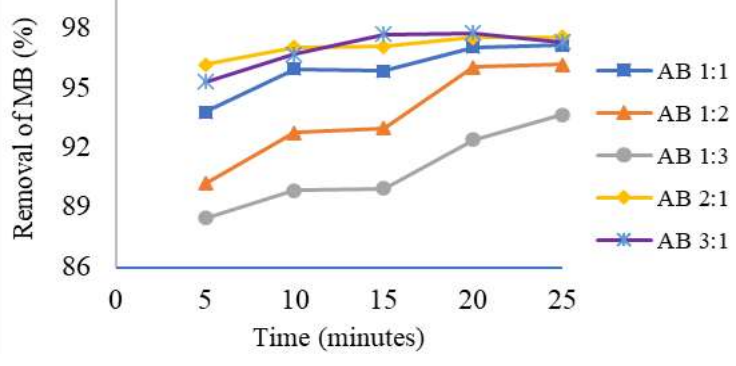

Figure 1. Removal of methylene blue by using adsorbent $A B$

The ratio of adsorbent type mixture of $\mathrm{AB}$ 3: 1 meant that the fresh betel nut was 3 times effective than the regenerated one. The $\mathrm{AB}$ ratio of $2: 1$ and $3: 1$ had a higher percentage of adsorption efficiency compared to the other ratios, on the contrary, at a ratio of $1: 2$ and $1: 3$, percent of the adsorption efficiency is at the lowest. This showed that the number of A determined the amount of MB adsorbed.

Figure 2 described the correlation between the type of activated carbon AC to the methylene blue removal. The adsorption efficiency was $85.17-94.73 \%$. The maximum removal obtained at ratio $\mathrm{AC}$ of $1: 1$ at 25 minutes contact time with the amount of $94.73 \%$. The lowest adsorption efficiency occurred in the 1:3 AC ratio at 5 minutes stirring with the amount of $85.17 \%$. This meant that fresh betel nut activated carbon showed the greatest effect to the MB adsorption that the coconut shell based. The line formed by each ratio tends to increase unless the AC ratio of $1: 2$ at the stirring time of 10 minutes is decreased from $88.83 \%$ to $87,48 \%$ and the AC ratio of $2: 1$ when stirring 25 minutes decreases from $92.40 \%$ to $91.00 \%$. The optimum percent efficiency of adsorption occurs at a ratio of $1: 1$ in stirring time of 25 minutes, which is $94.73 \%$.

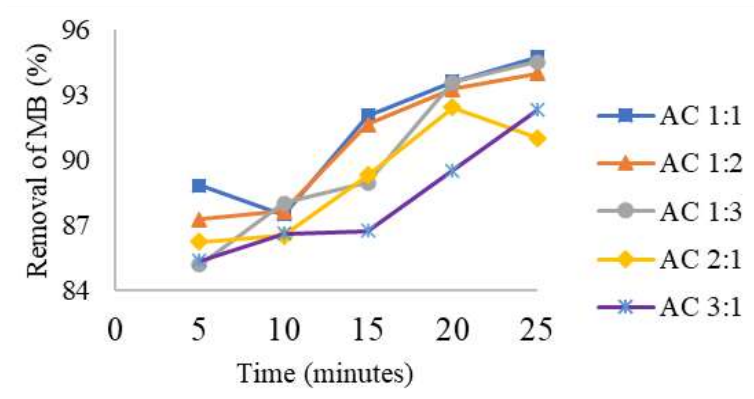

Figure 2. Removal of methylene blue by using adsorbent AC

The correlation between adsorbent $\mathrm{BC}$ in $\mathrm{MB}$ adsorption was shown at Figure 3. The methylene blue removal was $67.66-92.60 \%$. In each $\mathrm{BC}$ ratio, on average there was an increasing in percent adsorption efficiency or color degradation along the increasing of contact time. The maximum removal obtained at ratio $\mathrm{BC}$ of $1: 2$ at 25 minutes with amount of $92.60 \%$. The minimum removal of MB occurred at ratio $\mathrm{BC}$ of $2: 1$ at 5 minutes with the amount $67.66 \%$. It described that the fresh coconut shell 


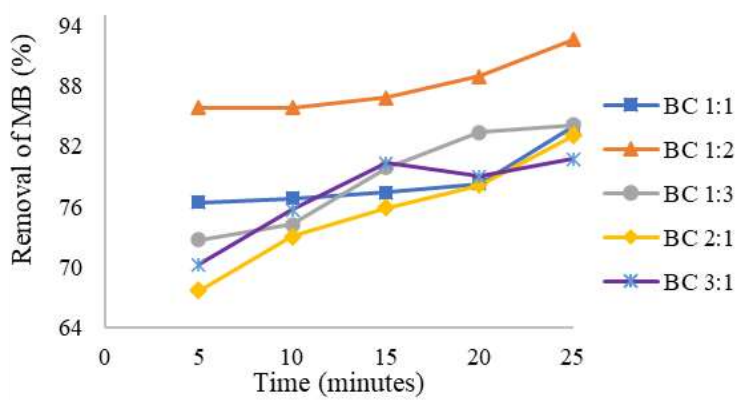

Figure 3. Removal of methylene blue by using adsorbent BC

activated carbon was more effective than the regenerated activated carbon based on betel nut.

From Figure 1, 2, and 3, It can be seen that the value of the percent adsorption range was $88.46-97.77 \%$ for $\mathrm{AB}, 85.17-94.73 \%$ for $\mathrm{BC}$, and $67.66-92.60 \%$ for $\mathrm{AC}$. The highest removal was $97.77 \%$ that occurred at adsorbent type of $\mathrm{AB}$ at ratio $3: 1$. This methylene blue removal was higher than the research result that described by $[11,13,14]$ and lower than result that produced by $[9,12]$. This concluded that the $A B$ adsorbent is the most effective compare to $\mathrm{AC}$ and $\mathrm{BC}$, because the percentage of adsorption (the number of adsorbates absorbed) is higher than the activated carbon $\mathrm{BC}$ and $\mathrm{AC}$. It also indicated that the regenerated betel nut still showed better performance than the fresh commercial activated carbon based on coconut shell. The activated carbon made from betel nut was a potential, economic, environment friendly adsorbent, and its regenerated was able to reutilize.

The maximum adsorption capacity of an adsorbent in MB removal can be analyzed by using isotherm model. Figure 4 showed the Freundlich isotherm to adsorb methylene blue in aqueous solution onto the combination adsorbent at a ratio of $1: 1$. The results of regression value from Freundlich isotherm (Figure 4) ranged from $0.9835-0.9982$, it indicated minimal deviation from experimental data. The value of $\mathrm{K}_{\mathrm{F}}$ and $1 / \mathrm{n}$ (Table 1) were determined from the intercept and the slope respectively. The greater $\mathrm{K}_{\mathrm{F}}$ was the best adsorption capacity. The $1 / \mathrm{n}$ measured the intensity of adsorption. The smaller $1 / \mathrm{n}$ was the greater heterogeneity. The $n$ value less than 1 indicated the cooperative and weak

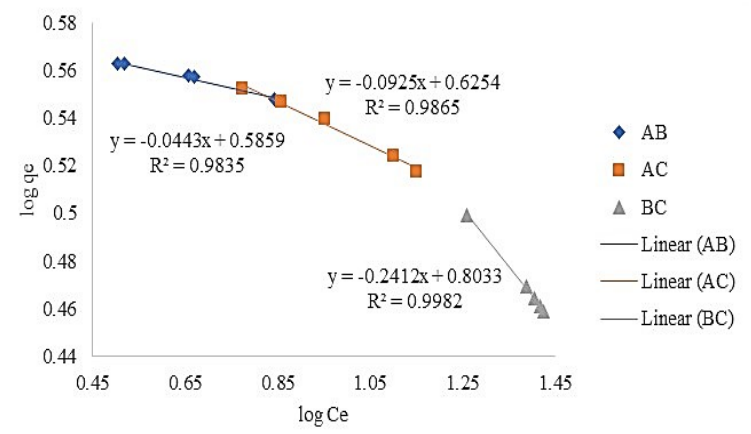

Figure 4. The freundlich isotherm curve at a ratio of $1: 1$
Table 1. Isotherm constant at ratio of 1:1.

\begin{tabular}{lcccccc}
\hline Isotherm & $\begin{array}{c}\text { Ads. } \\
\text { type }\end{array}$ & $\mathrm{R}^{2}$ & \multicolumn{5}{c}{ Constant } \\
\hline \multirow{4}{*}{ Freundlich } & $\mathrm{AB}$ & 0.9835 & $\mathrm{~K}_{\mathrm{F}}$ & $3.85 \mathrm{l} / \mathrm{mg}$ & $\mathrm{n}$ & 22.57 \\
& $\mathrm{AC}$ & 0.9865 & $\mathrm{~K}_{\mathrm{F}}$ & $4.221 / \mathrm{mg}$ & $\mathrm{n}$ & $\begin{array}{c}10.81 \\
\end{array}$ \\
& $\mathrm{BC}$ & 0.9982 & $\mathrm{~K}_{\mathrm{F}}$ & $6.361 / \mathrm{mg}$ & $\mathrm{n}$ & 4.15 \\
\hline \multirow{3}{*}{ Langmuir } & $\mathrm{AB}$ & 0.9999 & $\mathrm{q}_{\mathrm{m}}$ & $3.43 \mathrm{mg} / \mathrm{g}$ & $\mathrm{K}_{\mathrm{l}}$ & $4.761 / \mathrm{mg}$ \\
& $\mathrm{AC}$ & 0.9996 & $\mathrm{q}_{\mathrm{m}}$ & $3.12 \mathrm{mg} / \mathrm{g}$ & $\mathrm{K}_{\mathrm{l}}$ & $1.22 \mathrm{l} / \mathrm{mg}$ \\
& $\mathrm{BC}$ & 0.9997 & $\mathrm{q}_{\mathrm{m}}$ & $2.43 \mathrm{mg} / \mathrm{g}$ & $\mathrm{K}_{\mathrm{l}}$ & $0.241 / \mathrm{mg}$ \\
\hline
\end{tabular}

adsorption bond, and $1<\mathrm{n}<10$ favorable sorption process [19]. The $n$ value for $A B$ and $A C$ was over the favorable sorption. From the three type adsorbents, the BC adsorbent is the best for Freundlich isotherm at ratio $1: 1$, with the highest regression, maximum adsorption capacity and favorable adsorption occurred.

Figure 5 described the Langmuir isotherm to adsorb MB onto biomass-activated carbon at ratio 1:1. The value of $q_{m}$ and $K_{1}$ were computed from the slope and intercept of Langmuir plot. The $\mathrm{q}_{\mathrm{m}}$ indicated the theoretical of maximum adsorption capacity of the adsorbent and $\mathrm{K}_{1}$ indicated the Langmuir constant. The $\mathrm{R}^{2}$ was over 0.999 , it stated that the correlation between experimental and model was very tight. Experimental data for adsorption capacity was ranged from 2.64 to 3.67 $\mathrm{mg} / \mathrm{g}$. Table 1 showed the best fit for Langmuir isotherm in all type adsorbent at ratio $1: 1$, with $\mathrm{R}^{2}>0.999$ and maximum adsorption capacity $\left(\mathrm{q}_{\mathrm{m}}\right) 2.43-3.43 \mathrm{mg} / \mathrm{g}$.

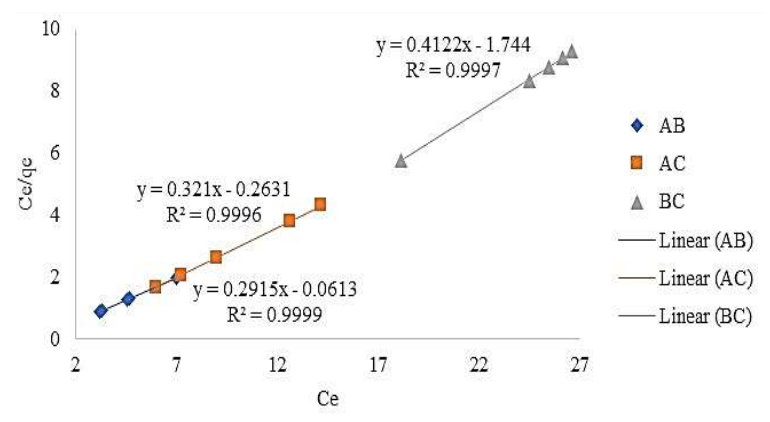

Figure 5. The Langmuir isotherm curve at a ratio of $1: 1$

The Freundlich and Langmuir isotherm to reduce methylene blue onto activated carbon at ratio 1:2 was seen at Figure 6 and 7. The constant was tabulated at Table 2 . The $\mathrm{R}^{2}$ value of Freundlich isotherm was range from 0.9808 to 0.9924 , with maximum

Table 2. Isoterm constant at ratio 1:2.

\begin{tabular}{|c|c|c|c|c|c|c|}
\hline Isotherm & $\begin{array}{l}\text { Ads. } \\
\text { type }\end{array}$ & $\mathrm{R}^{2}$ & \multicolumn{4}{|c|}{ Constant } \\
\hline \multirow{3}{*}{ Freundlich } & $\mathrm{AB}$ & 0.9808 & $\mathrm{~K}_{\mathrm{F}}$ & $3.981 / \mathrm{mg}$ & $\mathrm{n}$ & 15.53 \\
\hline & $\mathrm{AC}$ & 0.9924 & $\mathrm{~K}_{\mathrm{F}}$ & $4.30 \mathrm{l} / \mathrm{mg}$ & $\mathrm{n}$ & 9.92 \\
\hline & $\mathrm{BC}$ & 0.9917 & $\mathrm{~K}_{\mathrm{F}}$ & $4.47 \mathrm{l} / \mathrm{mg}$ & $\mathrm{n}$ & 8.58 \\
\hline \multirow{3}{*}{ Langmuir } & $\mathrm{AB}$ & 0.9996 & $\mathrm{q}_{\mathrm{m}}$ & $3.28 \mathrm{mg} / \mathrm{g}$ & $\mathrm{K}_{\mathrm{l}}$ & $2.321 / \mathrm{mg}$ \\
\hline & $\mathrm{AC}$ & 0.9998 & $\mathrm{q}_{\mathrm{m}}$ & $3.08 \mathrm{mg} / \mathrm{g}$ & $\mathrm{K}_{\mathrm{l}}$ & $1.06 \mathrm{l} / \mathrm{mg}$ \\
\hline & $\mathrm{BC}$ & 0.9996 & $\mathrm{q}_{\mathrm{m}}$ & $2.99 \mathrm{mg} / \mathrm{g}$ & $\mathrm{K}_{\mathrm{l}}$ & $0.811 / \mathrm{mg}$ \\
\hline
\end{tabular}




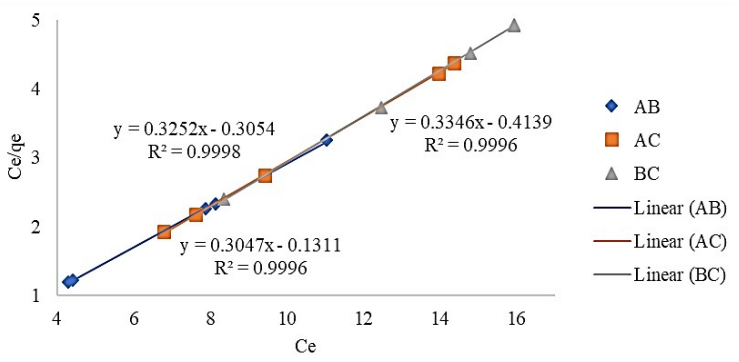

Figure 7. The Langmuir isotherm curve at a ratio of $1: 2$

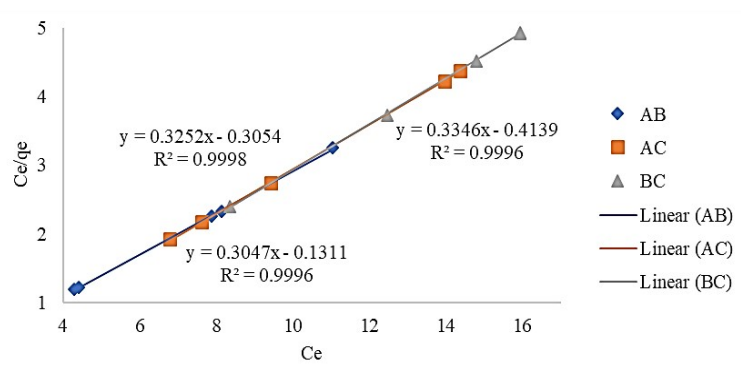

Figure 7. The Langmuir isotherm curve at a ratio of $1: 2$

adsorption capacity of $4.47 \mathrm{1} / \mathrm{mg}$ for $\mathrm{BC}$ adsorbent. The $\mathrm{n}$ value for $\mathrm{AC}$ and $\mathrm{BC}$ was in favorable adsorption range, while the $\mathrm{AB}$ was over. The value of the Freundlich isotherm correlation coefficient is lower than the Langmuir value.

Both in Table 1 and Table 2 showed the same trend results for Langmuir isotherm. Based on Table 2, Langmuir isotherm showed the best fit in all type adsorbent ratio 1:2. The regression of Langmuir isotherm model was over 0.999 with $\mathrm{q}_{\mathrm{m}} 2.99-3.28 \mathrm{mg} / \mathrm{g}$ that appropriate with experimental range. The best combination was $\mathrm{AB}$ adsorbent that showed the largest maximum adsorption capacity and Langmuir constant, with value of $3.28 \mathrm{mg} / \mathrm{g}$ and $2.32 \mathrm{l} / \mathrm{mg}$ respectively.

Figure 8-9 showed the same trend with adsorbent type ratio 1:3, that the regression value for Freundlich and Langmuir was over 0.9 , that indicated the close relation with experimental data [1]. The adsorption capacity for Freundlich was 4.25-6.90 1/mg. Based on $n$ value of Freundlich isotherm at Table 3, the favorable sorption $(1<\mathrm{n}<10)$ occurred at $\mathrm{AC}$ and $\mathrm{BC}$ adsorbent. The adsorption capacity for Langmuir ranged from 2.63 to $2.30 \mathrm{mg} / \mathrm{g}$ and constant ranged from 0.20 to $1.18 \mathrm{l} / \mathrm{mg}$. Based on Table 3, the best fit at ratio 1:3 was Langmuir

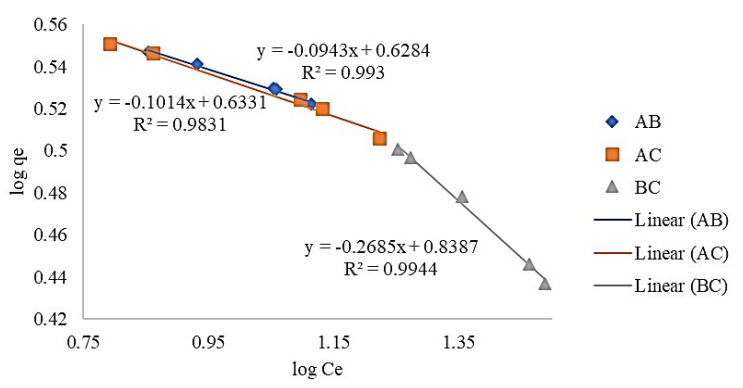

Figure 8. The Freundlich isotherm curve at a ratio of 1:3

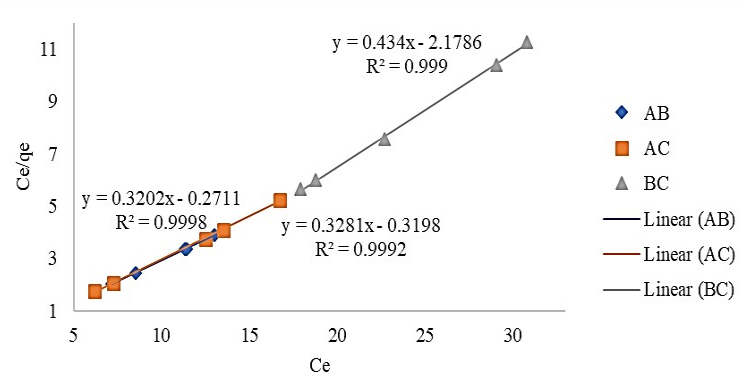

Figure 9. The Langmuir isotherm curve at a ratio of 1:3

Table 3. Isoterm constant at ratio of 1:3.

\begin{tabular}{lcccccc}
\hline Isotherm & $\begin{array}{c}\text { Ads. } \\
\text { type }\end{array}$ & $\mathrm{R}^{2}$ & \multicolumn{5}{c}{ Constant } \\
\hline \multirow{3}{*}{ Freundlich } & $\mathrm{AB}$ & 0.9930 & $\mathrm{~K}_{\mathrm{F}}$ & $4.25 \mathrm{l} / \mathrm{mg}$ & $\mathrm{n}$ & 10.60 \\
& $\mathrm{AC}$ & 0.9831 & $\mathrm{~K}_{\mathrm{F}}$ & $4.301 / \mathrm{mg}$ & $\mathrm{n}$ & 9.86 \\
& $\mathrm{BC}$ & 0.9944 & $\mathrm{~K}_{\mathrm{F}}$ & $6.901 / \mathrm{mg}$ & $\mathrm{n}$ & 3.72 \\
\hline \multirow{3}{*}{ Langmuir } & $\mathrm{AB}$ & 0.9998 & $\mathrm{q}_{\mathrm{m}}$ & $3.12 \mathrm{mg} / \mathrm{g}$ & $\mathrm{K}_{\mathrm{l}}$ & $1.18 \mathrm{l} / \mathrm{mg}$ \\
& $\mathrm{AC}$ & 0.9992 & $\mathrm{q}_{\mathrm{m}}$ & $2.63 \mathrm{mg} / \mathrm{g}$ & $\mathrm{K}_{\mathrm{l}}$ & $0.63 \mathrm{l} / \mathrm{mg}$ \\
& $\mathrm{BC}$ & 0.9990 & $\mathrm{q}_{\mathrm{m}}$ & $2.30 \mathrm{mg} / \mathrm{g}$ & $\mathrm{K}_{\mathrm{l}}$ & $0.201 / \mathrm{mg}$ \\
\hline
\end{tabular}

isotherm with adsorbent type of $A B, R^{2}$ of $0.9998, q_{m}$ of $3.12 \mathrm{mg} / \mathrm{g}$ and $\mathrm{K}_{1}$ of $1.18 \mathrm{l} / \mathrm{mg}$.

The isotherm for ratio 2:1 was shown at Figure 10 for Freundlich and Figure 11 for Langmuir. Both of them correlated with the experimental over 0.9 . Based on figure 10 and Table 4, the AB adsorbent type showed that process occurred over favorable sorption, with $n$ value 31.95. The highest adsorption capacity occurred at BC adsorbent with value $7.41 \mathrm{l} / \mathrm{mg}$ and heterogeneity value of 3.44. For Langmuir isotherm (figure 11 and Table 4), the perfect regression was reached by $\mathrm{AB}$ adsorbent

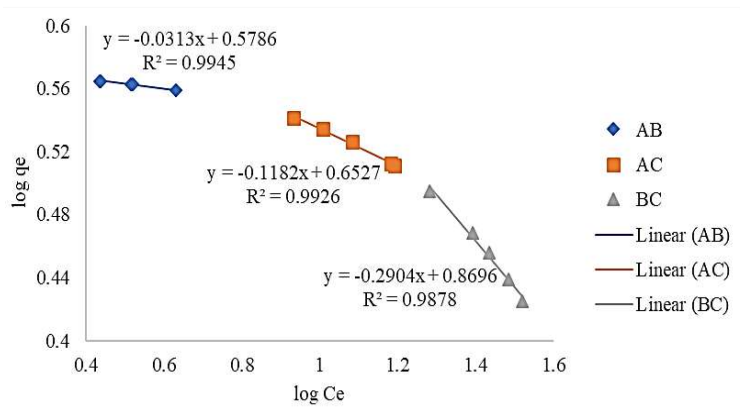

Figure 10. The Freundlich isotherm curve at a ratio of $2: 1$

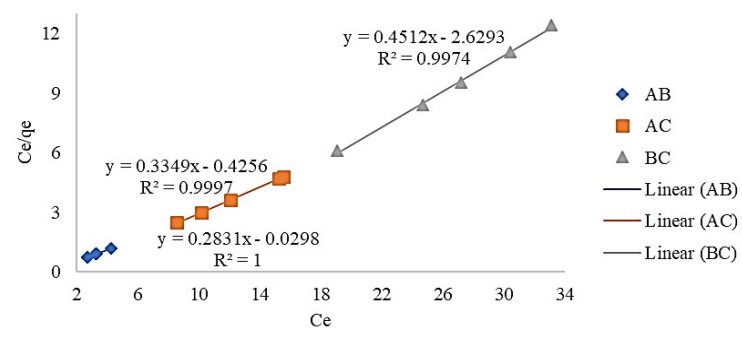

Figure 11. The Langmuir isotherm curve at a ratio of 2:1 
Table 4. Isotherm constant at ratio of 2:1.

\begin{tabular}{ccccccc}
\hline Isotherm & $\begin{array}{c}\text { Ads. } \\
\text { type }\end{array}$ & $\mathrm{R}^{2}$ & \multicolumn{5}{c}{ Constant } \\
\hline \multirow{4}{*}{ Freundlich } & $\mathrm{AB}$ & 0.9945 & $\mathrm{~K}_{\mathrm{F}}$ & $3.791 / \mathrm{mg}$ & $\mathrm{n}$ & 31.95 \\
& $\mathrm{AC}$ & 0.9926 & $\mathrm{~K}_{\mathrm{F}}$ & $4.501 / \mathrm{mg}$ & $\mathrm{n}$ & 8.46 \\
& $\mathrm{BC}$ & 0.9878 & $\mathrm{~K}_{\mathrm{F}}$ & $7.41 \mathrm{l} / \mathrm{mg}$ & $\mathrm{n}$ & 3.44 \\
\hline \multirow{3}{*}{ Langmuir } & $\mathrm{AB}$ & 1 & $\mathrm{q}_{\mathrm{m}}$ & $3.53 \mathrm{mg} / \mathrm{g}$ & $\mathrm{K}_{\mathrm{l}}$ & $9.501 / \mathrm{mg}$ \\
& $\mathrm{AC}$ & 0.9997 & $\mathrm{q}_{\mathrm{m}}$ & $2.99 \mathrm{mg} / \mathrm{g}$ & $\mathrm{K}_{\mathrm{l}}$ & $0.791 / \mathrm{mg}$ \\
& $\mathrm{BC}$ & 0.9974 & $\mathrm{q}_{\mathrm{m}}$ & $2.22 \mathrm{mg} / \mathrm{g}$ & $\mathrm{K}_{\mathrm{l}}$ & $0.171 / \mathrm{mg}$ \\
\hline
\end{tabular}

with $\mathrm{R}^{2}=1$, maximum adsorption capacity of $3.53 \mathrm{mg} / \mathrm{g}$ and Langmuir constant of $9.50 \mathrm{l} / \mathrm{mg}$.

Figure 12-13 showed the Freundlich and Langmuir isotherm at ratio 3:1. The range regression for Freundlich was 0.9914-0.9944, and for Langmuir was 0.9987-1. That meant the relation between experimental data and calculation was very tight, even perfect at ratio $2: 1$ and $3: 1$ for $\mathrm{AB}$ adsorbent. The $n$ value for $\mathrm{AC}$ and $\mathrm{BC}$ was appropriate with the favorable sorption. All the calculation result for $\mathrm{AB}$ adsorbent showed over favorable sorption at any ratios. The highest adsorption capacity $\left(\mathrm{K}_{\mathrm{F}}\right)$ was $8.14 \mathrm{l} / \mathrm{mg}$ that occurred at $\mathrm{BC}$ adsorbent with ratio of $3: 1$. Table 4 and 5 explained that the value of $\mathrm{R}^{2}$ equal 1 was the Langmuir isotherm model at $\mathrm{AB}$ adsorbent with the highest $\mathrm{q}_{\mathrm{m}}$ of $3.53 \mathrm{mg} / \mathrm{g}$ and $\mathrm{K}_{1}$ of $9.53 \mathrm{l} / \mathrm{mg}$. The range of qm suitable with the experimental data as amount $2.14-3.53 \mathrm{mg} / \mathrm{g}$.

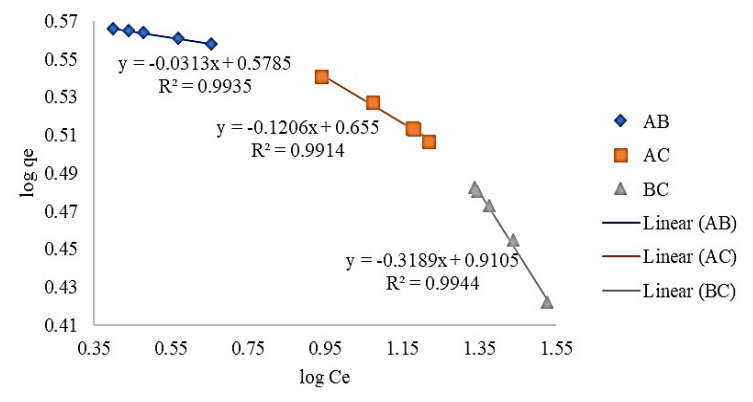

Figure 12. The Freundlich isotherm curve at a ratio of $3: 1$

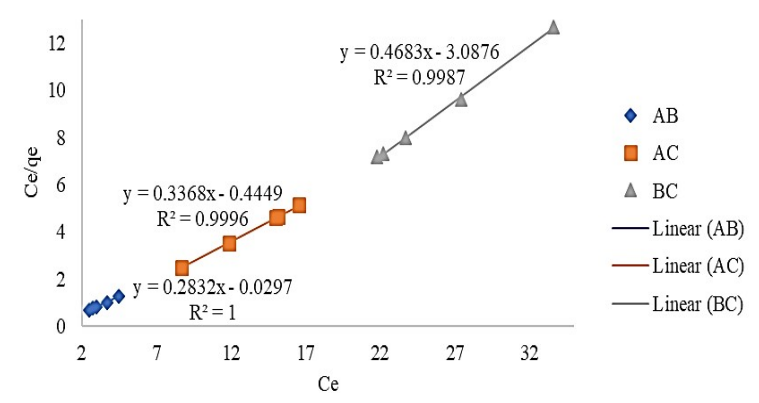

Figure 13. The Langmuir isotherm curve at a ratio of $3: 1$

Based on Figure 4-13 and Table 1-5, the regression value of Freundlich and Langmuir was over 0.9 , with $\mathrm{R}^{2}$ of Langmuir that slightly over the Freundlich in all type and ratio. The Freundlich isotherm considered to the $\mathrm{R}^{2}$ value and favorable sorption process $(n)$. The Langmuir
Table 5. Isotherm constant at ratio of 3:1.

\begin{tabular}{ccccccc}
\hline Isotherm & $\begin{array}{c}\text { Ads. } \\
\text { type }\end{array}$ & $\mathrm{R}^{2}$ & \multicolumn{5}{c}{ Constant } \\
\hline \multirow{4}{*}{ Freundlich } & $\mathrm{AB}$ & 0.9935 & $\mathrm{~K}_{\mathrm{F}}$ & $3.79 \mathrm{l} / \mathrm{mg}$ & $\mathrm{n}$ & 31.95 \\
& $\mathrm{AC}$ & 0.9914 & $\mathrm{~K}_{\mathrm{F}}$ & $4.52 \mathrm{l} / \mathrm{mg}$ & $\mathrm{n}$ & 8.29 \\
& $\mathrm{BC}$ & 0.9944 & $\mathrm{~K}_{\mathrm{F}}$ & $8.14 \mathrm{l} / \mathrm{mg}$ & $\mathrm{n}$ & 3.14 \\
\hline \multirow{3}{*}{ Langmuir } & $\mathrm{AB}$ & 1 & $\mathrm{q}_{\mathrm{m}}$ & $3.53 \mathrm{mg} / \mathrm{g}$ & $\mathrm{K}_{\mathrm{l}}$ & $9.531 / \mathrm{mg}$ \\
& $\mathrm{AC}$ & 0.9996 & $\mathrm{q}_{\mathrm{m}}$ & $2.97 \mathrm{mg} / \mathrm{g}$ & $\mathrm{K}_{\mathrm{l}}$ & $0.761 / \mathrm{mg}$ \\
& $\mathrm{BC}$ & 0.9987 & $\mathrm{q}_{\mathrm{m}}$ & $2.14 \mathrm{mg} / \mathrm{g}$ & $\mathrm{K}_{\mathrm{l}}$ & $0.151 / \mathrm{mg}$ \\
\hline
\end{tabular}

isotherm considered to the regression value and maximum adsorption capacity. The highest regression even perfect $\left(R^{2}=1\right)$ was occurred at Langmuir isotherm at $A B$ adsorbent type with ratio $3: 1, \mathrm{q}_{\mathrm{m}}=3.53 \mathrm{mg} / \mathrm{g}$, and $\mathrm{K}_{1}=9.53 \mathrm{l} / \mathrm{mg}$. This result concluded that the removal of methylene blue onto biomass-based activated carbon followed Langmuir isotherm. The same results also reported by $[9,15,20]$. The adsorption process between methylene blue and activated carbon was homogeneous, formed a monolayer surface, and chemically adsorption [19]. Even though the Langmuir isotherm concluded that chemical adsorption was occurred, the removal of $\mathrm{MB}$ could not say completely chemical. This was known from the calculation of adsorption energy that got $0.63 \mathrm{~kJ} / \mathrm{mol}$. The energy was $9-16 \mathrm{~kJ} / \mathrm{mol}$ for chemical adsorption and less than $8 \mathrm{~kJ} / \mathrm{mol}$ for physical adsorption [21].

\section{CONCLUSION}

This study focused on removal and isotherm adsorption of methylene blue onto combination of twotype adsorbent. The adsorbent was biomass-based activated carbon, that was fresh betel nut activated carbon (A), regenerated betel nut activated carbon (B), and commercial based of coconut shell activated carbon (C). The best results showed that the combination of fresh and regenerated betel nuts activated carbon (AB) with ratio of 3:1 removed $97.77 \%$ of methylene blue. This concluded that the $\mathrm{AB}$ adsorbent is the most effective compare to $\mathrm{AC}$ and $\mathrm{BC}$. It also indicated that the regenerated betel nut still showed better performance than the fresh commercial activated carbon based on coconut shell. The activated carbon made from betel nut was a potential, economic, environment friendly adsorbent, and the its regenerated was able to reutilize. The adsorption process of methylene blue in aqueous solution followed the Langmuir model with regression over 0.99 and adsorption capacity in the range of 2.14 $\mathrm{mg} / \mathrm{g}-3.53 \mathrm{mg} / \mathrm{g}$.

\section{ACKNOWLEDGMENT}

This research was supported by the Separation and Purification Laboratory, Engineering Faculty, Universitas Sriwijaya. The authors thank Universitas Sriwijaya for funding the research. 


\section{REFERENCES}

[1] Z. Derakhshan, M. A. Baghapour, M. Ranjbar, and M. Faramarzian, "Adsorption of methylene blue dye from aqueous solutions by modified pumice stone: kinetics and equilibrium studies," Health Scope, vol. 2, no. 3, pp. 136-144, 2013.

[2] M. T. Butt, F. Arif, T. Shafique, and N. Imtiaz, "Spectrophotometric Estimation of Colour in Textile Dyeing Wastewater," J. Chem. Soc. Pak., vol. 27, no. 6, pp. 627-630, 2005.

[3] J. S. Wu, C. H. Liu, K. H. Chu, and S. Y. Suen, "Removal of Cationic Dye Methyl Violet 2B from Water by Cation Exchange Membranes," J. Membr. Sci., vol. 309, no. 1, pp. 2239-2245.

[4] P. Purnawan, "Degradasi Zat Pewarna Naphtol dan Indigososl Limbah Industri Batik Jumputan dengan Sistem Elektrokoagulasi," in Simposium Nasional RAPIXXI, 2013.

[5] T. E. Agustina, E. Nurisman, P. Prasetyowati, N. Haryani, and L. Cundari, "Pengolahan Air Limbah Pewarna Sintetis dengan Menggunakan Reagen Fenton," in Prosiding Seminar Nasional Avoer ke-3, Palembang, Indonesia, 2011.

[6] M. N. Ismail, H. A. Aziz, M. A. Ahmad, and N. A. Yusoff, "Optimization of areca catechu Fronds as Adsorbent for Decolorization and COD Removal of Wastewater through the Adsorption Process," Sains Malays., vol. 44, no. 11, pp. 1609-1614, 2015.

[7] Z. Fallah and E. P. L. Roberts, "Combined adsorption/regeneration process for the removal of trace emulsified hydrocarbon contaminants," Chemosphere, vol. 230, pp. 596-605, Sep. 2019, doi: 10.1016/j.chemosphere.2019.04.224.

[8] M. Nainamalai, M. Palani, B. Soundarajan, and A. E. J.S.S, "Decolorization of synthetic dye wastewater using packed bed electro-adsorption column," Chem. Eng. Process. - Process Intensif., vol. 130, pp. 160-168, Aug. 2018, doi: 10.1016/ j.cep.2018.06.013.

[9] L. Cundari, A. N. Utari, and M. Septikarini, "Adsorption Capacity and Isotherm of Methylene Blue Removal in Aqueous Solution onto Regenerated Activated Carbon," IOP Conf. Ser. Mater. Sci. Eng., vol. 543, p. 012088, Jun. 2019, doi: 10.1088/1757-899X/543/1/012088.

[10] L. Cundari, K. F. Sari, and L. Anggraini, "Batch Study, Kinetic and Equilibrium Isotherms Studies of Dye Adsorption of Jumputan Wastewater onto Betel Nuts Adsorbent," J. Phys. Conf. Ser., vol. 1095, p. 012018, Sep. 2018, doi: 10.1088/1742-6596/ 1095/1/012018.

[11] R. A. Sanada, S. S. Moersidik, and N. Suwartha, "Adsorpsi Zat Warna Kationik (Methylene Blue) Menggunakan Karbon Aktif Tempurung Kelapa dan Batu Bara serta Efisiensi Regenerasinya," Repos. Univ. Indones., 2014.
[12] S. H. Kow, M. R. Fahmi, C. Z. Abidin, S. A. Ong, and N. Ibrahim, "Regeneration of spent activated carbon from industrial application by $\mathrm{NaOH}$ solution and hot water," J. Desalination Water Treat., vol. 57, no. 60, pp. 29137-29142, 2016, doi: 10.1080/19443994.2016.1168133.

[13] O. O. Bello, O. M. Adelaide, M. A. Hammed, and O. A. M. Popoola, "Kinetic and equilibrium studies of methylene blue removal from aqueous solution by adsorption on treated sawdust," Maced. J. Chem. Chem. Eng., vol. 29, no. 1, pp. 77-85, 2010.

[14] L. G. Hassan, B. N. Ajaka, K. J. Umar, D. M. Sahabi, A. U. Itodo, and A. Uba, "Comparative Batch and Column Evaluation of Thermal and Wet Oxidative Regeneration of Commercial Activated Carbon Exhausted with Synthetic Dye," Niger. J. Basic Appl. Sci., vol. 20, no. 2, pp. 93-104, 2012.

[15] L. Alcaraz, A. López Fernández, I. García-Díaz, and F. A. López, "Preparation and characterization of activated carbons from winemaking wastes and their adsorption of methylene blue," Adsorpt. Sci. Technol., vol. 36, no. 5-6, pp. 1331-1351, Jul. 2018, doi: $10.1177 / 0263617418770295$.

[16] J. Jaafari et al., "Adsorption Of P-Cresol On Al2O3 Coated Multi-Walled Carbon Nanotubes: Response Surface Methodology And Isotherm Study," J. Ind. Eng. Chem., vol. 57, no. 1, pp. 396454, 2018.

[17] E. Sahara, W. D. Sulihityas, and I. P. A. S. Mahardika, "Pembuatan dan Karakterisasi Arang Aktif dari Batang Tanaman Gumitir (Togetes Erecta) yang Diaktivasi dengan H3PO4," J. Kim., vol. 11, no. 1, pp. 1-9, 2017.

[18] L. Utami and L. Lazulva, "Pemanfaatan Limbah Kulit Buah Pinang (Areca chatecu L.) Sebagai Biosorben Untuk Mengolah Logam Berat Pb (II), ' J. Al-Kim., vol. 5, no. 2, pp. 109-118, 2017.

[19] D. A.O, "Langmuir, Freundlich, Temkin and Dubinin-Radushkevich Isotherms Studies of Equilibrium Sorption of Zn 2+ Unto Phosphoric Acid Modified Rice Husk," IOSR J. Appl. Chem., vol. 3, no. 1, pp. 38-45, 2012, doi: 10.9790/57360313845 .

[20] A. Albadarin, J. Mo, Y. Glocheux, S. Allen, G. Walker, and C. Mangwandi, "Preliminary Investigation Of Mixed Adsorbents For The Removal Of Copper And Methylene Blue From Aqueous Solutions," Chem. Eng. J., vol. 255, no. 525, pp. 2-18, 2014.

[21] G. Ghanizadeh and G. Asgari, "Adsorption Kinetics And Isotherm Of Methylene Blue and Its Removal From Aqueous Solution Using Bone Charcoal," React. Kinet. Mech. Catal., vol. 102, pp. 127-142, 2010, doi: https://doi.org/10.1007/ s11144-010-0247-2. 